\title{
Emergence rates from the benthos of the parasitic juveniles of gnathiid isopods
}

\author{
Alexandra S. Grutter ${ }^{1, *}$, Robert J. G. Lester ${ }^{1}$, Jack Greenwood ${ }^{2}$ \\ ${ }^{1}$ Department of Microbiology and Parasitology and ${ }^{2}$ Department of Zoology and Entomology, \\ The University of Queensland, Brisbane, Queensland 4072, Australia
}

\begin{abstract}
Variation in the rate at which parasitic gnathiid isopod juveniles emerged from the benthos at Lizard Island, Great Barrier Reef, Australia, was examined (1) every 4 or $8 \mathrm{~h}$ throughout the day and night over a $24 \mathrm{~h}$ period, (2) over a $12 \mathrm{~h}$ period during the day or night, and (3) during different lunar phases (weeks). The number of gnathiids sampled per 4 or $8 \mathrm{~h}$ was low, with only $30 \%$ of the traps containing gnathiids and the abundance ranging from 0 to 3 gnathiids $\mathrm{m}^{-2}$. The number of gnathiids that emerged over $12 \mathrm{~h}$, in contrast, ranged from 0 to $36 \mathrm{~m}^{-2}$. During the third and fifth weeks sampled, more gnathiids emerged during the day than at night. This coincided with the full moon and new moon. Most gnathiids that emerged from the reef during the day $(98 \%)$ had not fed, in contrast to those sampled at night $(71 \%)$. Of the gnathiids with no engorged gut, most $(97 \%)$ of those collected during the day were small $(\leq 1 \mathrm{~mm})$ compared to those collected at night $(19 \%)$, the latter being mostly $>1 \mathrm{~mm}$. Of the gnathiids with an engorged gut, most were sampled at night $(83 \%)$ and $97 \%$ were $>1 \mathrm{~mm}$ in size. These percentages suggest differences in the emergence behaviour among life stages or species of gnathiids. This study, which shows that gnathiids do emerge during the day and supports other studies showing that gnathiids also attack fishes during the day, has important implications for understanding the role of cleaner fish and their main food source, gnathiids, as it shows there is a constant source of gnathiids emerging from the reef during the day and night in search of hosts.
\end{abstract}

KEY WORDS: Crustacea $\cdot$ Gnathiidae $\cdot$ Isopoda $\cdot$ Ectoparasites $\cdot$ Great Barrier Reef $\cdot$ Demersal zooplankton $\cdot$ Emergence behaviour $\cdot$ Emergence traps $\cdot$ Lunar periodicity

\section{INTRODUCTION}

Parasites play an important role in the biology of fishes, and can affect their behaviour, health, and distribution (Rohde 1993). Isopods associated with fish are a significant component of the parasite fauna of fishes and are important economically and ecologically, yet little is known of their biology (see review by BunkleyWilliams \& Williams 1998). Fish isopods feed on host blood, plasma in wounds and fish tissue, sometimes resulting in impressive tissue damage (Bunkley-

*E-mail: a.grutter@mailbox.uq.edu.au
Williams \& Williams 1998). Some fish isopods negatively affect commercially important fishes (Williams \& Bunkley-Williams 1996). Superinfections by isopods can kill fishes (Williams \& Bunkley-Williams 1994b); fishes in captivity are especially susceptible (Mugridge \& Stallybrass 1983). On coral reefs, cymothoid isopods affect the growth and fecundity of damselfish (Adlard \& Lester 1995) and other fish (Lester \& Roubal 1995).

Gnathiid isopods are one of the most common isopods on fishes (Grutter 1994, Grutter \& Poulin 1998), but because of their high mobility (Grutter 1995), they have been overlooked in most parasitological surveys (e.g. see checklist of parasites in Lester \& Sewell 1989). They are only parasitic when juvenile; adults remain in the benthos and do not feed (Wägele 1988). Gnathi- 
ids cause tissue damage (Honma \& Chiba 1991) and can kill fishes in captivity (Mugridge \& Stallybrass 1983).

Recently gnathiids have been shown to play a significant role in cleaning interactions on the Great Barrier Reef (GBR). Cleaner fish remove such large numbers of isopods from client fishes (Grutter 1996) that isopod abundance on fishes is reduced daily (Grutter 1999a,b, Grutter \& Hendrikz 1999). Gnathiid abundances on fishes, however, recover overnight, suggesting that infection rates are high (Grutter 1996). Infection studies using caged fishes show that gnathiids infect fish mainly in the late afternoon and at night and to a lesser extent during the day (Grutter 1999b). This is in contrast to gnathiids in the Red Sea, which only attack fish at night (Paperna \& Por 1977). Gnathiids on the GBR do infect fishes during the day, which suggests that not only are the gnathiids removed by cleaners replaced at night, but that they are also replaced during the day. Little, however, is known of the habits of gnathiids prior to infecting fishes, particularly when in the plankton or benthos.

Gnathiids, although considered 'permanent' parasites by Bunkley-Williams \& Williams (1998), appear only to spend minutes or hours at a time on fishes (Monod 1926, Paperna \& Por 1977, A.S.G. unpubl. data), spending most of their time in the benthos to digest their blood meal and to moult and reproduce (Monod 1926, Wägele 1988). They have also often been captured in plankton nets. When and at what rate they emerge from the benthos into the water column to seek hosts are unknown. It is also unclear whether the infection rates of fishes reflect the emergence rates of gnathiids from the benthos. It has been suggested that gnathiids only attack fishes at night (Potts 1973, Paperna \& Por 1977), although Grutter (1999b) found that attacks also occurred during the day. Their emergence from the benthos may also vary with the lunar cycle (Jacoby \& Greenwood 1988). Most zooplankton migration studies have sampled gnathiids during the night only (Alldredge \& King 1977, Stepien \& Brusca 1985, Jacoby \& Greenwood 1988) or over 24 h (Hammer \& Zimmerman 1979); only a few have compared day and night, and these studies were in California (Hobson \& Chess 1976, Hammer 1981). To understand the dynamics of gnathiid infections and their interactions with fishes on coral reefs, it is essential to understand whether gnathiids also emerge from the benthos during the day.

This study examined temporal patterns of emergence of gnathiids from the benthos using emergence traps deployed (1) every 4 or $8 \mathrm{~h}$ over a $24 \mathrm{~h}$ period, (2) over a $12 \mathrm{~h}$ period during the day or night, and (3) over a $12 \mathrm{~h}$ period during the day or night repeated every fortnight for $6 \mathrm{wk}$ at different lunar phases.

\section{METHODS AND MATERIALS}

Sampling. Juvenile gnathiids were sampled using emergence traps following Jacoby \& Greenwood (1988). Briefly, traps were made of $100 \mu \mathrm{m}$ nylon mesh in a pyramidal shape with a $1 \mathrm{~m}^{2}$ base of polyvinylchloride pipe filled with lead shot. A 11 plastic bottle filled with water and attached to a funnel $50 \mathrm{~cm}$ above the base acted as a cod end. Foam floats gave the funnel and cod end positive buoyancy. To prevent gaps between the base and an uneven substratum, a skirt of $100 \mu \mathrm{m}$ mesh weighted with lead strips extended $0.5 \mathrm{~m}$ below the trap.

Three traps per reef were placed at random by a SCUBA diver or snorkeler on a different patch reef (52 to $125 \mathrm{~m}^{2}$ ) (for map see Reefs 14, 15, and 16 in Grutter 1996) on 3 successive days. Sampling, when weather permitted, was generally done on the day before, during, and after each quarter of the moon phase; traps were allocated randomly to each of these reefs; 6 lunar quarters were sampled beginning 30 December 1997. Traps were placed in the water at 06:30 h for $24 \mathrm{~h}$. To compare emergence rates between day and night, sampling bottles were exchanged at 18:30 h, except for Week 1, when traps were sampled every $4 \mathrm{~h}$ (and after $8 \mathrm{~h}$ between 22:30 and 06:30 h) to examine variation in emergence patterns within the day or night. Due to rough weather conditions, only 2 reefs were sampled in the first and last quarters; only 2 traps were used on the last day/reef due to damage to 1 of the traps; 3 traps were used on all other days.

Samples were returned to the laboratory and filtered using a $62 \mu \mathrm{m}$ filter made with a plankton mesh and fixed in $10 \%$ formalin in sea water. Gnathiids were counted using a sorting tray and a dissecting microscope $(\times 25)$, measured (including mouth parts but excluding uropods), and categorised as gnathiids with or without an engorged gut.

Statistical analyses. Variation in the abundance of gnathiids emerging among weeks and time of day (day and night) was examined with $\chi^{2}$ goodness-of-fit tests. Many of the traps contained zero gnathiids; thus, the sum of gnathiids per treatment was used; expected values were based on sampling effort (total number of gnathiids per treatment divided by number of traps); treatments with zero expected values were omitted. Weekly variation was examined by (1) testing each reef separately for an effect of week over the entire day (day plus night), (2) combining all 3 reefs and testing for an effect of week over the entire day, and (3) as for Expt 2, but for day and night separately. Variation between day and night was examined by (1) comparing each week separately and testing for effect of time of day, and (2) using the total number of gnathiids trapped over the $6 \mathrm{wk}$ and testing for effect of time of day. 
The number of gnathiids per size class was too small to test for an effect of sampling time (lunar phase) on size; hence gnathiids were pooled across sampling times. Because gnathiids increase in size as their gut becomes engorged with host fluids, the effect of time of day was examined separately for gnathiids with and without an engorged gut. Yate's corrected $\chi^{2}$ tests were used to test for differences among size classes of gnathiids without an engorged gut between day and night and to test whether the presence or absence of engorged guts varied between day and night. The numbers of gnathiids with an engorged gut were too small to test for differences among size classes of gnathiids between day and night, so they were pooled and $\chi^{2}$ goodness-of-fit tests used to test the effect of size and time separately.

\section{RESULTS}

The number of gnathiids which emerged per unit area usually ranged between 0 and $6 \mathrm{~m}^{-2}$ per $12 \mathrm{~h}$, except on 8 occasions ( 2 times during the new moon, and 6 times during the second full moon), when the number ranged between 8 and $36 \mathrm{~m}^{-2}$, adding greatly to the variation in abundance at these times (Fig. 1). All gnathiids were juveniles, except for 1 unidentified male collected during the night on Week 5 (new moon); this male was not included in the analyses. Gnathiid abundance varied among weeks at all levels tested. Gnathiid abundance on each reef, combined over the entire day (day plus night), varied among weeks on all reefs (Reef

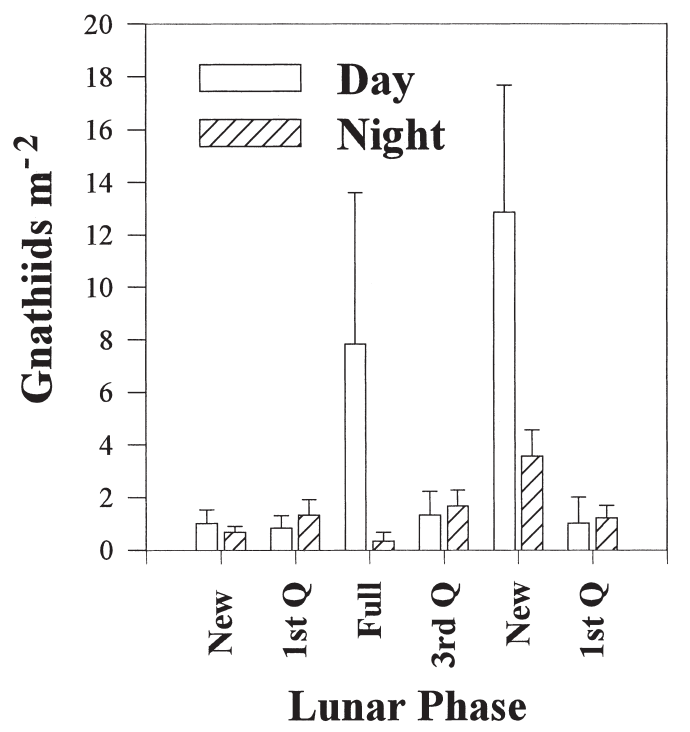

Fig. 1. Mean abundance of gnathiids per $\mathrm{m}^{2}$ collected during day or night and on different weeks (lunar phases). Error bars $=+\mathrm{SE}$
Table 1. Proportion of gnathiids found in emergence traps sampled over day or night tabulated by presence/absence of engorged gut and by size

\begin{tabular}{|lcc|}
\hline & Day & Night \\
\hline No engorged gut & 0.975 & 0.716 \\
Engorged gut & 0.025 & 0.284 \\
$\leq 1 \mathrm{~mm}$ & 0.967 & 0.188 \\
$>1 \mathrm{~mm}$ & 0.033 & 0.812 \\
\hline
\end{tabular}

14: $\chi^{2}=43.5, \mathrm{df}=3, \mathrm{p}<0.001$; Reef 15: $\chi^{2}=107.3, \mathrm{df}=3$, $\mathrm{p}<0.001$; Reef 16: $\left.\chi^{2}=34.5, \mathrm{df}=4, \mathrm{p}<0.001\right)$. Gnathiid abundance, combined across all reefs and over the entire day, also varied among weeks $\left(\chi^{2}=172.2 \mathrm{df}=5\right.$, $\mathrm{p}<0.001)$. Finally, gnathiid abundance sampled during the day or night only, combined across all reefs, also varied among weeks (day: $\chi^{2}=34.1$, df $=5$, p < 0.001; night: $\left.\chi^{2}=136.9, \mathrm{df}=5, \mathrm{p}<0.001\right)$.

Variation in gnathiid abundance between day and night, when tested separately for each week, was not significant for Weeks 1,2 , and 4 (all $\chi^{2}<2.5$, df $=1$, p > $0.1) ;$ in contrast it differed between the day and night for Weeks 3 and 5, which coincided with a full and new moon respectively (all $\chi^{2}>40, \mathrm{df}=1, \mathrm{p}<0.001$ ); the 'expected' value for the gnathiid abundance sampled over the day for Week 6 was too low to conduct a $\chi^{2}$ goodnessof-fit analysis ( 6 gnathiids were collected in 5 traps over the night, 2 gnathiids were collected in 2 traps over the day). When summed across all reefs and weeks, the abundance of gnathiids differed significantly between day and night $\left(\chi^{2}=80.4, \mathrm{df}=1, \mathrm{p}<0.001\right)$.

Only $30 \%$ of the traps sampled for 4 or $8 \mathrm{~h}$ throughout the day and night had gnathiids, and the numbers ranged from 1 to 3 gnathiids $\mathrm{m}^{-2}$. When pooled for each time period and standardised to $4 \mathrm{~h}$, the abundance was (time sampled in h) 1 (10:30), 3 (14:30), 5 (18:30), 2 (22:30), and 0.5 (06:30). Because so few of the traps had gnathiids, the data were not analysed further.

The proportion of gnathiids with no engorged guts was higher during the day (98\%) than at night $(71 \%)$ $\left(\chi^{2}=31.44, \mathrm{df}=1, \mathrm{p}<0.001\right)$ (Table 1). Of the gnathiids with no engorged gut, most $(97 \%)$ of those collected during the day were small $(\leq 1 \mathrm{~mm})$ compared to those collected at night $(19 \%)$, the latter being mostly $>1 \mathrm{~mm}$ $\left(\chi^{2}=126.15\right.$, df $\left.=1, p<0.001\right)$ (Table 1$)$. Of the gnathiids with an engorged gut, most were sampled at night $(83 \%)\left(\chi^{2}=9.78, \mathrm{df}=1, \mathrm{p}=0.002\right)$, and $97 \%$ were $>1 \mathrm{~mm}$ in size $\left(\chi^{2}=19.17, \mathrm{df}=1, \mathrm{p}<0.001\right)$.

\section{DISCUSSION}

Gnathiid emergence rates, measured over 12 h, varied between day and night, with more emerging dur- 
ing the day, but only on Weeks 3 and 5, which coincided with the full and new moon respectively. The finding of daytime emergence was surprising, as most studies suggest that gnathiids emerge from the benthos mainly at night (Hobson \& Chess 1976, Stepien \& Brusca 1985). Only a few studies have found gnathiids during the day (Hammer 1981, Hobson \& Chess 1976), and Hobson \& Chess (1976) found less gnathiids emerging during the day.

Possibly, as Grutter's (1999b) study of infection rates of fishes suggests, gnathiids do emerge from the benthos at a higher rate in the late afternoon. Hence, including the late afternoon with the rest of day in the $12 \mathrm{~h}$ trials may have inflated the overall emergence rates during the day. The traps used in this study did not capture enough gnathiids over a 4 or $8 \mathrm{~h}$ period to examine variation in emergence patterns within the day or night. Another approach is needed to resolve this question.

Emergence rates of gnathiids varied among weeks (lunar phases) probably as a result of higher abundances during the third and fifth weeks, which coincided with a full and new moon respectively. The first week sampled on the new moon revealed very low numbers of gnathiids; thus, whether there is a lunar effect on gnathiid emergence patterns is uncertain. However, the traps sampled during the first week were also sampled every 4 or $8 \mathrm{~h}$, whereas the rest were sampled every $12 \mathrm{~h}$; thus the possibility that the low numbers of gnathiids found are a sampling artefact cannot be excluded. Jacoby \& Greenwood (1988) suggested that gnathiids at Heron Island, also on the GBR, emerged from the reef in higher numbers at full moon, possibly because fishes were more easily located. The present study also found that gnathiids emerged more at full moon, but this was largely due to gnathiids emerging during the day. Thus, factors other than host location are likely to be involved, such as increased dispersal due to higher tidal variation.

The lack of an engorged gut indicates that a gnathiid has not fedi such a gnathiid would be most likely to emerge from the benthos to seek a host. Almost all the gnathiids sampled during the day and a large majority of those sampled at night had no engorged gut. This suggests that gnathiids seek hosts during both day and night, but the larger number sampled during the day suggests they do so more during the day and confirms infection studies of gnathiids which show that gnathiids infect fishes during both day and night (Grutter 1999b).

The number of gnathiids emerging from the reef in search of hosts is likely to be related to the number infecting fishes. As gnathiids are the main food source of cleaner fish (Grutter 1996, 1997), cleaners therefore have a constant source of gnathiids not only to replace those eaten during the day, but to re-infect cleaned fishes overnight. However, the risk of predation by cleaners in higher for gnathiids during the day. It is surprising, therefore, that gnathiids emerge during the day when a safer strategy would be to emerge at night only, when no cleaning by fish (Grutter 1996) or shrimp has been observed (A.S.G. pers. obs.).

Interestingly, most of the gnathiids that had an engorged gut were sampled at night. Therefore, gnathiids that had already fed moved out of the benthos mostly at night. Since most planktivorous predators are diurnal, gnathiids entering the plankton at night may be at a lower risk from predators. Gnathiids return to the benthos to digest their blood meal and to moult; why they should return to the water column when they have an engorged gut is unclear. It is unlikely that gnathiids with an engorged gut were seeking another blood meal as gnathiids quickly leave fishes after becoming engorged (Monod 1926, A.S.G. unpubl. data) and readily moult to the next stage (A.S.G. pers. obs.), suggesting they only feed once during each juvenile stage. Gnathiids are most probably vulnerable to predation when moulting; thus, it is possible that gnathiids may seek a suitable site to moult during the night. Third-stage larvae must also find suitable mates (Uptown 1987), and so may move about at night in search of inhabited burrows for mates.

Gnathiids without an engorged gut that were sampled during the day were smaller than those sampled at night. Gnathiids have 3 juvenile stages (Wägele 1988); hence the above differences may be due to variation in emergence patterns among juvenile stages, with younger stages emerging during the day and older stages emerging at night; alternatively they may be due to variation in emergence patterns among species. Currently, gnathiids are identified from adult males only (Cohen \& Poore 1994). A method of identifying juvenile gnathiids using rDNA has been developed (Grutter et al. 2000). Such method will enable the identification of the different types of gnathiids found in this study.

Acknowledgements. Many thanks to M. Johnson, C. Bansemer, M. Srinivasi, R. Tollrian, and A. Hoggett for their generous assistance in the field at all hours of the day and night. We are grateful to the staff of Lizard Island Research Station for their help with field logistics, to L. Lestrange for laboratory assistance, and to J. Hendrikz for statistical advice. The study was funded by an ARC Postdoctoral Research fellowship and an ARC Small Grant to A.S.G.

\section{LITERATURE CITED}

Adlard RD, Lester RJG (1995) Dynamics of the interaction between the parasitic isopod, Anilocra pomacentri, and the coral reef fish, Chromis nitida. Parasitology 109: $311-324$ 
Alldredge AL, King JM (1977) Distribution, abundance and substrate preference of demersal reef zooplankton at Lizard Island Lagoon, Great Barrier Reef. Mar Biol 41: $317-333$

Bunkley-Williams L, Williams EH Jr (1998) Isopods associated with fishes: a synopsis and corrections. J Parasitol 84(5): 893-896

Cohen BF, Poore GCB (1994) A phylogeny of the Gnathiidae (Crustacea: Isopoda) with descriptions of new genera and species from south-eastern Australia. Mem Mus Victoria 54:271-397

Grutter AS (1994) Spatial and temporal variations of the ectoparasites of seven coral reef fish from Lizard Island and Heron Island, Australia. Mar Ecol Prog Ser 115:21-30

Grutter AS (1995) A comparison of methods for sampling ectoparasites of coral reef fishes. J Mar Freshw Res 46: 897-903

Grutter AS (1996) Parasite removal rates by the cleaner wrasse Labroides dimidiatus. Mar Ecol Prog Ser 130: 61-70

Grutter AS (1997) Spatio-temporal variation and feeding selectivity in the diet of cleaner fish Labroides dimidiatus. Copeia 1997:346-355

Grutter AS (1999a) Cleaner fish really do clean. Nature 398: 672-673

Grutter AS (1999b) Infestation dynamics of gnathiid isopod juveniles parasitic on the coral-reef fish Hemigymnus melapterus (Labridae). Mar Biol 135:545-552

Grutter AS, Hendrikz J (1999) Diurnal variation in the abundance of parasitic gnathiid isopod larvae on coral reef fish: its implications in cleaning interactions. Coral Reefs 18(2): 187-191

Grutter AS, Poulin R (1998) Cleaning of coral reef fishes by the wrasse Labroides dimidiatus: ecological and phylogenetic influences. Copeia 1998:120-127

Grutter AS, Morgan JAT, Adlard RD (2000) Characterising parasitic gnathiid isopod species and matching life stages with ribosomal DNA ITS2 sequences. Mar Biol 36:201-205

Hammer RM (1981) Day-night differences in the emergence of demersal zooplankton from a sand substrate in a kelp forest. Mar Biol 62:275-280

Hammer RM, Zimmerman RC (1979) Species of demersal zooplankton inhabiting a kelp forest ecosystem off Santa Catalina Island, California. Bull S Calif Acad Sci 78: 199-206

Hobson ES, Chess JR (1976) Trophic interactions among fishes and zooplankters near shore at Santa Catalina Island, California. Fish Bull 74(3):567-598

Honma Y, Chiba A (1991) Pathological changes in the

Editorial responsibility: Charles Birkeland (Contributing

Editor), Honolulu, Hawaii, USA branchial chamber wall of stingrays, Dasyatis spp., associated with the presence of juvenile gnathiids (Isopoda, Crustacea). Gyobyo Kenkyu 26:9-16

Jacoby CA, Greenwood JG (1988) Spatial, temporal, and behavioural patterns in emergence of zooplankton in the lagoon of Heron Reef, Great Barrier Reef. Mar Biol 97: 309-328

Lester RJG, Roubal FR (1995) Phylum Arthropoda. In: Woo PTK (ed) Fish diseases and disorders, Vol 1. Protozoan and metazoan infections. CAB International, Wallingford, p 475-598

Lester RJG, Sewell KB (1989) Checklist of parasites from Heron Island, Great Barrier Reef. Aust J Zool 37:101-128

Monod T (1926) Les Gnathiidae. Essai monographique (morphologie, biologie, systematique). Mém Soc Sci Nat Phys Maroc 13:1-668

Mugridge RER, Stallybrass HG (1983) A mortality of eels, Anguilla anguilla L., attributed to Gnathiidae. J Fish Biol 6:81-82

Paperna I, Por FD (1977) Preliminary data on the Gnathiidae (Isopoda) of the Northern Red Sea, the Bitter Lakes, and the Mediterranean and the biology of Gnathia piscivora n. sp. Rapp P-V Réun Comm Int Explor Sci Mer Médit 24(4):195-197

Potts GW (1973) Cleaning symbiosis among British fish with special reference to Crenilabrus melops (Labridae). J Mar Biol Assoc UK 53:1-10

Rohde K (1993) Ecology of marine parasites, 2nd edn. CAB International, Wallingford, p 1-298

Stepien CA, Brusca R (1985) Nocturnal attacks on nearshore fishes in southern California by crustacean zooplankton. Mar Ecol Prog Ser 25:91-105

Uptown NPD (1987) Gregarious larval settlement within a restricted intertidal zone and sex differences in subsequent mortality in the polygynous saltmarsh isopod Paragnathia formica (Crustacea: Isopoda). J Mar Biol Assoc UK 67:663-678

Wägele JW (1988) Aspects of the life-cycle of the Antarctic fish parasite Gnathia calva Vanhöffen (Crustacea: Isopoda). Polar Biol 8:287-291

Williams EH Jr, Bunkley-Williams L (1994) Four cases of unusual crustacean-fish associations and comments on parasitic processes. J Aquat Anim Health 6:202-208

Williams EH Jr, Bunkley-Williams L (1996) Parasites offshore, big game sport fishes of Puerto Rico and the Western North Atlantic. Puerto Rico Department of Natural and Environmental Resources, San Juan, and Department of Biology, University of Puerto Rico, Mayaguez

Submitted: October 28, 1999; Accepted: June 20, 2000

Proofs received from author(s): October 9, 2000 